\title{
Process-Product Approach to Writing: the Effect of Model Essays on EFL Learners' Writing Accuracy
}

\author{
Parastou Gholami Pasand (Corresponding author) \\ English Department, Guilan University \\ Zibakenar, Rasht, Iran
}

Tel: 0098-0132-468 2069 E-mail: Parastou_gholami@yahoo.com

\author{
Eshrat Bazarmaj Haghi \\ English Department, Guilan University \\ 98 Shohada Street, Rasht, Iran \\ Tel: 0098-0131-8836380 E-mail: Eshrat_haghi@yahoo.com
}

Received: 20-08- 2012

Accepted: 16-09- 2012

Published: 01-01- 2013

doi:10.7575/ijalel.v.2n.1p.75

URL: http://dx.doi.org/10.7575/ijalel.v.2n.1p.75

\begin{abstract}
Writing is one the most important skills in learning a foreign language. The significance of being able to write in a second or foreign language has become clearer nowadays. Accordingly, different approaches to writing such as product approach, process approach and more recently process-product approach came into existence and they have been the concern of SL/FL researchers. The aim of this study is to answer the question that whether the use of an incomplete model text in process-product approach to writing and asking the learners to complete the text rather than copying it can have a positive impact on EFL learners' accuracy in writing. After training a number of EFL learners on using process approach, we held a two-session writing class. In the first session students wrote in the process approach, and in the second one they were given a model text to continue in the process-product approach. The writing performance of the students in these two sessions was compared in term of accuracy. Based on the students' writing performance, we came to the conclusion that completing the model text in process-product writing can have a rather positive influence in some aspects of their writing accuracy such as punctuation, capitalization, spelling, subject-verb agreement, tense, the use of connectors, using correct pronouns and possessives. Also the results of the paired t-test indicate that using a model text to continue increased students' writing accuracy.
\end{abstract}

Keywords: EFL writing, process-product approach, model text, writing accuracy

\section{Introduction}

Writing is one the most important skills in learning a foreign language the nature of which has become clearer nowadays. It involves the development of an idea, the capture of mental representations of knowledge, and of experience with subjects.

Writing accuracy is an important concern in EFL writing classrooms. Students' writing performance is usually evaluated based on how accurate they are in lexico-grammatical areas, spelling and punctuation. In some classes students are asked to write after analyzing the main components of a sample text. They are actually required to copy the sample text's organizational characteristics. This is what is done in product-based approaches. In process-product approaches, where a model text is present, students should also prepare their piece of writing after a careful analysis of the sample text.

The aim of this study is to engage EFL learners in a kind of process-product approach to writing in which they will be presented with a sample text but instead of copying it they are asked to continue the text based on their own ideas. We believed that in this way the sample will act as a guide rather than as a means to an end. Our main issue in this regard is whether writing in this way has any effect on the students' writing accuracy or not.

The research question that we pursue is: Does using a model text in process-product approach and asking the students to continue it affect their accuracy in writing?

We also hypothesize that using an incomplete model text in the process-product approach to writing and asking the EFL learners to complete it on their own will have a positive effect on their writing accuracy.

\section{Review of literature}

Although research in process approaches to writing and also product approaches abound, there is a gap in literature regarding process-product approaches to writing, and this gap is specifically evident in Iranian EFL context. 


\subsection{Product-based Approach}

There are different approaches to teaching writing. One of the earliest approaches is product-based approach in which as stated by Tangpermpoon (2008), students will start from pre-writing to composing and to correcting. In this approach what is emphasized is raising students' awareness, especially in grammatical structures. According to Nunan (1999), in this approach the focus is on the final product which should be a coherent, error-free text and students will initiate, copy and transform models provided by textbooks or by teachers.

Modeling is at the center of this approach and it has always been regarded as a beneficial source for providing feedback to students as well as being an effective teaching tool, if appropriately integrated into the context of writing process. (Saeidi \& Sahebkheir, 2011)

Murray (1980) refers to some disadvantages of using model texts in L2 writing classes; the main disadvantage is that model texts prevent L2 learners' creativity. Particularly the way that model texts have been used in the product-based approach has been criticized that is reading the text, analyzing it and then starting to write. (as cited in Saeidi \& Sahebkheir, 2011, p. 131)

Furthermore, Escholz point outs that the product-based approach encourages the learners to use the same plan in different settings, apply the same forms, regardless of content, thereby inhibiting writers rather than empowering or liberating them. On the other hand, Escholz emphasizes that when models are appropriately integrated into the content of the writing process, they become useful teaching tools. Models can lead students to be aware of various aspects of writing such as style, vocabulary, organization and structure. (as cited in Saeidi \& Sahebkheir, 2011, p.)

\subsection{Process-based Approach}

In this approach the focus is on the steps involved in drafting and redrafting a piece of work (Nunan, 1999). Its chief concern is to discover what writers do when they write, by focusing on different stages that the writers will go through.

Matsuda (2003) states,

The notion of writing as process was introduced to L2 studies by Vivian Zamel (1976), who argued

that advanced L2 writers are similar to L1 writers and can benefit from instruction emphasizing the process of writing. Rather than the view of writing as a reproduction of previously learned syntactic

or discourse structures, the process-based approach emphasized the view of writing as a

process of developing organization as well as meaning. (p. 21)

As cited in Tangpermpoon (2008), O'Brian (2004) defines the concept of process approach as an activity in which writing is regarded as the discovery of meaning and ideas.

Schmitt (2002) indicates that the process approach considers the composing act as a recursive, explanatory and generative process. Myles (2002) also believes that, the process approach to writing is only appropriate when learners have the opportunity to receive feedback on their written text. Therefore, process-based approach to writing, by giving an opportunity to learners to receive feedback, allows students time to reflect and seek input as they reshape their plans, ideas and language (Myles, 2002). In addition, the process-based approach is seen to be more effective than the productbased approach, since it allows the student to explore and develop personal approach to writing (Sutikno, 2008).But in spite of all its advantages, lack of a good model can be seen as a drawback in this approach. According to Torghabeh, Hashemi and Ahmadi (2010), the model can partly eliminate the burden of devising content from the learners.

\subsection{Process-Product Approach to Writing}

As cited in Tangpermpoon (2008), Brookes and Grundy (1990), believe that if we teach the writing approaches separately this will result in unbalanced L2 writing performance. Therefore, by integrating these approaches to writing, EFL learners can transfer the skills they have gained from each approach from one mode to another and have a much better writing performance.

Accordingly, writing teachers can start teaching EFL learners the rhetorical patterns in the product-based approach and familiarize them with different text organizations through working on models, and combine it with feedback parts and interaction in the process-based approach.

\subsection{Accuracy in Writing}

Polio (1997), pointed that the focus of current writing pedagogy on writing process and idea generation resulted in putting less emphasis on getting students to write error-free sentences. Indeed, he mentions that process-oriented approaches in teaching L2 writing insist that editing wait until the final drafts.

Most of the studies up to the present time have been concerned with the effect of teacher's feedback on the accuracy of students' writing (Chandler, 2003; Truscott, 2004; Myles, 2002; Bitcher, Young \& Cameron, 2005; Diab, 2005). Only a few studies have considered the role of model texts on EFL learners' writing accuracy (Saeidi \& Sahebkheir, 2011; Sahebkheir 2011). 


\section{Research Method}

\subsection{Design}

A quasi-experimental design was used in the present study, in which a group of Iranian EFL learners took part in a sixsessions writing classes. The first four sessions were conducted in order to familiarize the learners with the processes involved in the process- approach to writing, and the final two sessions aimed at investigating the effect of completing an incomplete model text on their writing accuracy.

\subsection{Participants}

The participants of this study were twelve intermediate EFL learners, half of them were males and the other half females, at intermediate level .They study English as a foreign language in one of the institutions in Iran, Rasht .All of the participants were adult students between 13 to 15 years old.

\subsection{Instruments and Materials}

The main instrument used in this study was a checklist mostly adapted from a study by Erel and Bulut (2007) and modified after analyzing writings' of the participants of the present study. Also, two kinds of tasks were used in this study which required the students to write in English. In the first task the students were asked to write according to the process approach. The topic of writing was selected based on the students' interest. After generating ideas by having a classroom discussion they started to write going through different phases of drafting, revising, redrafting and editing. In the second task which was done based on process-product approach, the students were asked to write about the same topic after a model text was explained and discussed in terms of its organization, structure, etc. They were required to complete the model text on their own way.

\subsection{Procedure}

After conducting four sessions of writing classes- each one lasting one hour- for training the participants on how to write first in a process approach and then in a process-product approach, they were asked to participate in the first session of our writing classrooms. In the first session, after providing some topics, the students were asked to choose their topic of interest, and then discussed it in pairs and shared their ideas with the class. In the next phase, they started writing their first draft in pairs, then the papers were exchanged and each pair received peer feedback on their writing. The teacher researcher's role was scaffolding and helping students during writing and also in the feedback part. This procedure was repeated for writing the second draft, and at last the students wrote their final draft in pairs.

In the second session, the participants were firstly asked to read a model text which was prepared based on the topic they wrote about in the previous session. The model text was prepared based on a short essay written about the subject of writing with some modifications to suit it to the level of students. After reading and class discussion about its organization, lexical items, grammatical points and so on, the students started writing their own paper continuing the model text. They went through the same steps of the process approach to writing, that is they started writing their first draft in pair and exchanging their writings with other pairs and receiving feedback. Finally they started writing their final drafts, implementing revisions on their writings.

\section{Analysis}

To compare the accuracy of students' writing performance, we prepared a checklist. In it we considered some of the main writing errors based on the results of a study on error treatment in writing feedback by Erel and Bulut in 2007, conducted in an EFL context. After a general analysis of our subjects' writing performance we modified some of the items in the checklist. The reliability of our checklist was checked by having two teachers working in the institutes in which the study was conducted, review students' written texts. The items in the checklist included punctuation, capitalization, spelling, singular-plural form, subject-verb agreement, tense, missing words, article usage, connectors, preposition ,pronouns, possessives, inappropriate word, wrong negation and word order. In order to have more stable results two raters marked students' papers. We manually counted the number of students' errors regarding these criteria in their papers written in both sessions. Then the mean number of errors for each category was calculated and compared using the SPSS software version 16.

In the second round of analysis we decided to give holistic scores to students' writings in both sessions. For this purpose, considering the above-mentioned criteria we considered the scales from 0 to 20 and subtracted .5 point for each error type and then a total score was given to each paper. Next, the mean score and standard deviation were calculated using the SPSS software. Finally, a paired t-test was used to compare the mean score of the writing accuracy of students in each session.

\section{Results}

\subsection{Inter-rater reliability}

The computed Pearson correlation for the students' writing accuracy in the first session was $(r=.897, p<.05)$ and for the second session was $(r=.915, \mathrm{p}<.05)$, which indicates a high positive relationship between the scores given by the two raters.

Our hypothesis in this study was that using an incomplete model text in the process-product approach to writing and asking the EFL learners to complete it on their own will have a positive effect on their writing accuracy. 
Table 1 shows the mean of each error type when the participants were required to write based on the process approach, and when they were provided with a model text and asked to continue it on their own using process-product approach to writing. The writing errors include: punctuation, capitalization, spelling, subject-verb agreement, tense, the use of connectors, using correct pronouns and possessives.

Table 1. Mean number of errors in process approach and process-product approach

\begin{tabular}{lcc}
\hline Error Type & $\begin{array}{c}\text { Process approach } \\
\text { Mean }\end{array}$ & $\begin{array}{c}\text { Process-product approach } \\
\text { Mean }\end{array}$ \\
\hline Punctuation & 1 & 0.5 \\
Capitalization & 2 & 0 \\
Spelling & 0.83 & 0.16 \\
Inappropriate Verb & 0 & 0.33 \\
Singular-Plural Form & 0.5 & 1.33 \\
Subject-Verb Agreement & 0.16 & 0 \\
Tense & 1.6 & 0.66 \\
Missing Words & 0.16 & 0.5 \\
Article Usage & 0.66 & 0.83 \\
Connector & 1.16 & 0.33 \\
Preposition & 0.33 & 0.83 \\
Pronouns & 0.66 & 0.16 \\
Possessives & 0.16 & 0 \\
Inappropriate Word & 2 & 2.5 \\
Wrong Negation & 0 & 0.16 \\
Word Order & 0 & 0.33 \\
\hline
\end{tabular}

Note: $\mathrm{p}<.05$

The table as a whole does not indicate a significant decrease in the mean number of errors in the second session when an incomplete model text was prepared and students were asked to continue it. However, it shows that there are some error types which approximately decreased in the second session. These error types include: errors in punctuation from the mean number of 1 error in the first session in which process approach was used to 0.5 in the second session in which students were asked to write based on process-product approach requiring to complete a model essay, capitalization from the mean number of 2 errors in the first session to 0 in the second session, subject-verb agreement and the use of possessives from the mean of 0.16 in students' first writing to 0 in their second writing.

Table 2 shows the results of the t-test. It can be seen that the mean score of students' writing performance with regard to their accuracy in writing increased in the second session with the presence of a model text. The result of the t-test also indicates that the difference is significant.

Table 2. Paired t-test for scores of accuracy in the first and second writing sessions

\begin{tabular}{llllll}
\hline & Mean & SD & T & Sig & df \\
\hline Session 1 & 14.16 & 2.27 & -8.80 & 2.57 & 5 \\
Session 2 & 15.58 & 1.80 & -8.80 & 2.57 & 5 \\
\hline
\end{tabular}

Note: $\mathrm{p}<.05$

\section{Discussion and Conclusion}

The main focus of our study was to find the effect of using a model text on students writing accuracy in an EFL writing classrooms based on process-product approach. We have asked the subjects of our study to participate in a two-session preparatory writing class and they were required to engage in writing at two different sessions, one based on the process approach and the other according to a process-product approach in which a model text was also provided. Our aim was to see whether the use of a model text in the process-product approach and asking the learners to continue the essay rather than copying from the text will increase the writing accuracy of EFL learners. Based on the results of our study, it is found that some of the writing errors of students including punctuation, capitalization, spelling, subject-verb agreement, tense, the use of connectors, using correct pronouns and possessives were reduced in the second session in which the incomplete model text was used.

Contrary to our expectations, there were some error types which increased in the second sessions. These include: inappropriate verb usage, using wrong negation, and using prepositions, and word order. The results of the paired t-test also indicate a significant difference in the writing performance of the students.

In light of our research question that is "Does using a model text in process-product approach and asking the students to continue it affect their writing accuracy?" we can conclude that using a model text and asking the students to continue it can improve the students' writing accuracy in some aspects of their writing but not all the aspects. 
Considering our hypothesis in which we assumed that the model text will have a positive impact on students' writing accuracy, based on the results of the t-test, generally we can conclude that our hypothesis was confirmed, and using a model text in process-product approach in which the students were asked to continue it, positively influence their writing accuracy.

\subsection{Limitations of the Study}

This study has its own limitations the most important of them is that because of the time constraints and restrictions in conducting our research in an institution we could not have more sessions to access more samples of students' writing. Therefore, further research is needed to ensure the impact of using model text in the way that was used in this study that is by having the learner to complete the model text rather than imitating it, on their L2 writing accuracy. Also more longitudinal studies are needed to investigate the impact of model texts on increasing the writing accuracy of EFL learners using integrated approach to writing.

\section{References}

Bitchener, J., Young, S., \& Cameron, D. (2005). The effect of different types of corrective feedback on ESL student writing. Journal of Second Language Writing, 14, 191-205.

Diab, R. L. (2005). EFL university students' preferences for error correction and teacher feedback on writing. TESL Reporter, 38(1), 27-51.

Erel, S. \& Bulut, D. (2007). Error treatment in L2 writing: A comparative study of direct and indirect coded feedback in Turkish EFL context. Sosyal Bilimler Enstitüsü Dergisi Sayl , 22(1), 397-415.

Matsuda P. K. (2003). Second language writing in the twentieth century: A situated historical perspective. In Kroll (Ed.) Exploring the dynamics of second language writing. Cambridge: Cambridge University Press.

Montague, N. (1995). The process oriented approach to teaching writing to second language learners. New York State Association for Bilingual Education Journal. 10(2), 13-24.

Myles, J. (2002). Second language writing and research: the writing process and error analysis in student texts. TESL$E J, 6(2)$.

Nunan, D. (1999). Second Language Teaching and Learning. U.S.: Heinle \& Heinle

Polio, C. G. (1997). Measures of linguistic accuracy in second language writing research. Language Learning, 47(1), 101-143.

Saeidi, M., Sahebkheir, F. (2011). The effect of model essays on accuracy and complexity of EFL learners' writing performance. Middle- East Journal of Scientific Research, 10(1), 130- 137.

Schmitt, N. (2002). An Introduction to Applied Linguistics. (Ed.). London: Arnold \& Oxford University Press.

Sutikno, M.K. (2008). Responding to students' writing. (Teaching writing or assessing it?). Journal Pendidikan Penabur, 10(7), 51-59.

Tangpermpoon, T. (2008). Integrated approaches to improve students' writing skills for English major students. $A B A C$ Journal, 28 (2), 1-9.

Torghabeh, R.A., Hashemi, M.R., \& Ahmadi, H, Sh. (2010). Writing through literature: a novel approach to EFL writing instruction. Iranian EFL Journal, 6(4), 7-23. 